\title{
Journal of Knowledge Management, Emerald \\ The Impact of Open-Border Organization Culture and Employees' Knowledge, Attitudes, and Rewards with regards to Open Innovation: An Empirical Study
}

\author{
Deemah Alassaf, Marina Dabić, Dara Shifrer, Tugrul Daim \\ Corresponding author Marina Dabić
}

\section{Citation}

Alassaf, D., Dabić, M., Shifrer, D. and Daim, T. (2020), "The impact of openborder organization culture and employees' knowledge, attitudes, and rewards with regards to open innovation: an empirical study", Journal of Knowledge Management, Vol. ahead-of-print No. ahead-of-

print. https://doi.org/10.1108/JKM-02-2020-0122

\begin{abstract}
Purpose - The objective of this paper is to fill a significant research gap in academic literature pertaining to Open Innovation. In order to do so, this paper empirically tests the impact of organizational culture, employees' knowledge, attitudes, and rewards as antecedents and mediators of Open Innovation adoption in organizations, facilitating a more thorough understanding by utilizing an empirical multi-level approach.

Design/methodology/approach - This paper analyses the results of the "Identification of Industrial Needs for Open Innovation Education in Europe" survey through a quantitative analysis using logistic regression models. This survey includes 528 employees working in 28 different industrial sectors in 37 countries, most of which are in Europe.

Findings - The results suggest a positive impact of organizational characteristics on the adoption of Open Innovation (i.e. including the adoption of outside-in and inside-out open innovation activities in participating organizations), showing that the openness of an organization's culture increases its likelihood of adopting an Open Innovation paradigm. More importantly, the results highlight the positive mediating effect of employees' knowledge and rewards on this relationship.
\end{abstract}


Practical implications - The proposed multi-level approach offers new insight into organizational knowledge. It enables the improvement of Open Innovation and Knowledge Management practices in organizations by assisting practitioners and academics in recognizing the relationship between organizational culture; employees' knowledge, attitudes, and rewards; and the adoption of the Open Innovation paradigm.

\section{Social implications}

This paper offers a possible explanation on why open-border cultures are more likely to have a successful open innovation adoption, by relating it to factors that advance in the presence of an open-border culture, such as active participation of OI relative departments in knowledge sourcing and knowledge exchange, and rewarding employees for open innovation activities.

Originality/value - This paper presents a new framework which links organizational culture to Open Innovation, moving on from merely examining culture in terms of its positive or negative impact on Open Innovation adoption. It contributes to research on the Open Innovation paradigm and Knowledge Management by highlighting the significance of antecedents and mediators from a multi-level perspective using multiple units of analysis. Most previous studies focus on a single unit of analysis.

Keywords - Open Innovation, Organization Culture, External Knowledge, Internal Knowledge, Rewards, Knowledge Sourcing, Knowledge Exchange. 


\section{The Impact of Open-Border Organization Culture and Employees' Knowledge, Attitudes, and Rewards with regards to Open Innovation: An Empirical Study}

\section{INTRODUCTION}

Open Innovation (OI) has been recognized as one of the most important factors related to societal development worldwide (Fini et al., 2018; Ahn et al., 2019). It accelerates the exchange of knowledge and technology between continents, countries, firms, and individuals, creating new business opportunities in established and emerging sectors.

A noticeable shift from Closed Innovation to OI has been increasingly made by organizations in order to commercialize their knowledge, especially as the OI paradigm commercializes internal ideas through external channels by collaborating with outside resources, generating additional value (Chesbrough, 2004). As such, interest in OI has been continuously growing in the field of scientific research due to its high influence on industrial and public policies

(West et al., 2014; Chesbrough et al., 2011; Chesbrough et al., 2014; Chen et al., 2019). 
Responding to the EU's new societal and community needs, both academics and practitioners have recognized and acknowledged the growing trend of organizations opening up their innovation strategy to enable them to survive in today's dynamic world (Lichtenthaler and Lichtenthaler, 2009; Spithoven et al., 2013; Urbinati et al., 2020; Švarc and Dabić, 2019; Fakhar Manesh et al., 2020). The new paradigm has been broadly accepted and adopted by both large international organizations and SMEs (Mortara and Minshall, 2011; Van de Vrande et al., 2009, Expósito et al., 2019).

In this paper we empirically highlight the mediating impact of OI antecedents such as organizational culture, employees' attitudes and knowledge, and rewards on open innovation by conducting an empirical analysis based on a quantitative approach. More specifically, the main open innovation outcome tested in this study is the adoption of open innovation in participating companies, which occurs as they engage in outside-in and/or inside-out open innovation activities. More importantly, unlike previous studies that analyzes a single antecedent at a time, this paper analyzes the antecedents-OI relationship using a comprehensive theoretical multi-level approach that divides these concepts into several elements and then draws relationships between them collectively.

According to the growing body of literature on OI, organizational culture has been identified as a significant challenge associated with the OI paradigm (Boschma, 2005; Carbone et al., 2010; Lichtenthaler, 2011; Nakagaki and Fetterhoff, 2012; Van de Vrande et al., 2009). It has been argued that a valuable organizational culture enables the successful handling of common difficulties faced during the adoption process, including dealing with exterior entities and the internal integration of employees, organizational resources, and rules, leading to a smoother adoption of OI (Van de Vrande et al., 2009). Moreover, a culture that appreciates external 
capabilities and knowledge is essential for OI (Bogers et al., 2018; Gassmann et al. 2010), as it has a vital role in integrating organizational processes and paving the way for organizations to adjust to the external domain (Denison and Mishra, 1995).

In order to comprehensively understand the relationship between organizational culture and OI adoption, we must look at additional factors that may have a mediating influence and can further explain this relationship, such as employees' knowledge, attitudes, and rewards. It has been argued that employees' attributes have a great impact on the adoption of OI (Harison and Koski, 2010; Huizingh, 2011). Since few studies of OI antecedents, especially on individuals and culture, have been introduced in OI literature (Bogers et al., 2017; Durst and Ståhle, 2013), an important contribution of this study is to fill this gap in scholarly literature by empirically testing the impact of organizational culture - which denotes organizational level - on OI adoption; providing a detailed and thorough analysis by looking at the ways in which individuals' knowledge and attitudes can facilitate an understanding of the culture's impact on OI adoption. Also, this study contributes to the literature with a multi-level analysis approach conducted to advance the theoretical concept by dividing it into several elements and then highlighting the relationships between them at diverse levels of analysis.

The focus of this research was influenced by the European Union's economy and employment growth, which has been directly linked to the shift towards an innovation and knowledge-based economy. As part of this shift, modern innovation processes now require a much faster reaction than ever before, wherein organizations require a skilled labor force to face the challenges of modern innovation-driven economies (Pfotenhauer et al., 2019). However, only a small amount of research has been able to explain the organizational characteristics and employees' skills required to deal with the challenges of external engagement (Salter et al., 2014), 
as organizations concurrently design and adopt OI strategies. This paper aims to highlight some of the essential adoption characteristics and skills necessary in order to understand their impact. Accordingly, this analysis is further expanded through the examination of more factors that might mediate the relationship between open-border organization culture and OI adoption, such as employees' active participation in knowledge sourcing and knowledge exchange practices, and rewarding OI related activities in order to enhance our understanding of this relationship (Dabić et al., 2019). Hence, the paper tries to answer the following research questions:

1. How does an organization's open-border culture relate to the likelihood of its adoption of Open Innovation?

2. Do employees' positive attitudes towards sharing and receiving knowledge, their active participation in knowledge sourcing and knowledge exchange, and the rewards associated with Open Innovation adoption contribute to this relationship?

Considering these questions and objectives, this paper is divided into five sections. After the introduction, an overview of the theoretical background on OI and open-border organization culture is provided. This overview also includes the mediating factors of employees' attitudes towards external and internal knowledge in an organizational context, along with the respective relationships between knowledge sourcing and knowledge exchange, and rewards and firm size in OI practices.

Additionally, this paper outlines the methods and methodology conducted through four sections, using data from the "Identification of Industrial Needs for Open Innovation Education in Europe" survey. The fourth section provides results and findings and proposes three models. Finally, a fifth section concludes this research by making a special reference to the limitations of the research conducted, offering future lines of research. These results suggest that the active 
participation of employees in relevant departments to OI in knowledge sourcing and knowledge exchange, as well as rewarding OI activities, mediate the relationship between open-border organization culture and OI adoption in firms, and they explain this relationship to some extent. Also, at the end of this paper, we suggest that a better exploration and articulation of the combined fields of OI and organizational practice and reward systems is required.

\section{LITERATURE REVIEW \& HYPOTHESIS DEVELOPMENT}

\section{Open Innovation}

A Google Scholar search of “Open Innovation”, up until January of 2020, delivers over 3.9 million results, and Henry Chesbrough's 2003 book has gathered more than 20,441 citations (Open Innovation, 2020). OI implies that companies should look for external ways to search for and use ideas that lie beyond their recognized boundaries (Chesbrough, 2006). As the interest in exploring this new paradigm has continued to increase, related literature has also increased, highlighting its benefits and advantages (Vanhaverbeke et al., 2014; Van de Vrande et al., 2009; Bogers et al., 2018). More importantly, any recent arguments regarding innovation in large corporations are eventually linked to the topic of OI.

Granting a business access to a much larger pool of external knowledge and ideas makes it a more attractive venture to pursue. Thus, many organizations have begun to adopt the OI model as an essential organizational adaptation to environmental shifts (Chesbrough, 2006). Through open innovation, customers can be creatively engaged in the design and production of the product. Their active engagement in customizing the products promotes the creation of unique and original products. Besides, through open innovation a network of related firms is created that enables firms to efficiently address many customers concurrently (Bonfanti, 2018). However, pushing the advantages of OI aside, the process of adopting an OI paradigm and earning its benefits is not as 
easy as it seems and requires a process of several phases (Chiaroni et al., 2011). In fact, many companies interested in adopting this model have been faced with constraints that hindered the adoption process. Scholarly literature highlights several of these obstacles, including but not limited to: insufficient knowledge, cultures or modes of organization, and bureaucratic elements (Hoffman and Schlosser, 2001; Mohr and Spekman, 1994).

\section{Open-border Organizational culture}

Academic literature shows that employee resistance and the absence of commitment have both been recognized as obstructions to the adoption of OI (Chesbrough and Crowther, 2006; Lichtenthaler and Lichtenthaler, 2009; Popa et al., 2017; Van de Vrande et al., 2009). More importantly, organizational culture and employee's characteristics both complement each other. In fact, generally, employees with knowledge and talent are driven by commitment, which serves as an important condition for an innovative culture, in which they are recognized as intangible assets that the organization employs to maintain its competitiveness (Muffatto, 1998; Michie and Sheehan, 2003; Papa et al., 2018). Open-border organization culture is a vital competency when it comes to OI adoption (Lin et al., 2019). In open-border cultures, ideas that come from external resources are as valuable as those from internal resources with regards to OI (Chesbrough, 2006). According to Ferraris et al. (2020) in an open innovation paradigm, it is critical to have an innovation-oriented culture in addition to examining different solutions for production processes in order to create value. Focusing on stability instead of creating change could obstruct the innovation processes, especially that open innovation necessitates change as well as innovative mind-sets, talents and knowledge. Hence, innovation-oriented cultures enable organizations to create and commercialize new technologies regularly (Büschgens et al., 2013). 
However, recent literature on OI has posited that open-border organization culture is a key challenge to the implementation of the OI paradigm (Naqshbandi et al., 2015). This has been categorized into three different processes. The outside-in process enhances the organization's own knowledge by combining suppliers, customers, and external knowledge sourcing (Laursen and Salter, 2006; Lettl et al., 2006; Piller and Walcher, 2006). In addition, the inside-out process is also used by companies as a means for OI. It refers to growing technology by offering internal ideas to an external environment. Finally, the coupled process combines the outside-in process with the inside-out process (Enkel, 2009). Adopting these processes guides organizations as they compete with their rivals by enabling them to keep up with the pace of technological advancements and protect their competitive advantage (Canik et al., 2017). Furthermore, an advantageous organizational culture enables an organization to identify dynamically changing problems when adapting to the integration of external and internal organizational resources, employees, and rules to support the external adaptation (Pool, 2000); simplify the OI adoption process (Van de Vrande et al., 2009); and make external collaborations effective (Boschma, 2005). On the other hand, a negative culture can constrain and hinder collaborations, thus restricting the adoption of OI (Van de Vrande et al., 2009).

H1: Open organization culture will relate positively with the adoption of Open Innovation.

\section{Employee Attitude to External Knowledge}

In order to cultivate an OI culture, employees need to adopt an OI attitude and modify their actions appropriately (Nakagaki and Fetterhoff, 2012). However, an important element of OI is that it involves research classes that are embedded in between or across different levels of analysis. Most research available on OI focuses on a single level of analysis, either at a firm level (i.e. the impact of organizational culture on OI) or at an individual level (i.e. the impact of employees' 
knowledge and attitude on OI) separately (Bogers et al., 2017; Chesbrough and Crowther, 2006; Durst and Ståhle, 2013; Harison and Koski, 2010; Huizingh, 2011; Lichtenthaler and Lichtenthaler, 2009; Van de Vrande et al., 2009). This notion brings us to the current lack of a comprehensive understanding of the impact that both levels collectively have on OI adoption. Hence, a multi-level analysis should be considered key to improving theoretical concepts, specifically as it divides these concepts into several elements and then draws relationships between them at diverse levels of analysis. This approach could result in significant outcomes that could develop theoretical knowledge and increase the value of the OI paradigm to organizations (Bogers et al., 2017; Gupta et al., 2007; Salvato and Rerup, 2011). Moreover, employees' attitudes towards change are critical to OI adoption and firm performance (Singh et al., 2019). As employees' job stability increases, they may lose their appetite for new and innovative methods and procedures, choosing the predictability of their secure and recognizable environments and the confidence it brings them instead (Katz, 1982). This often results in poor performance and unnecessarily repeated efforts. This is known as Not Invented Here (NIH) syndrome, wherein a project group with a stable structure believes it owns the monopoly of the knowledge in its area, leading it to discard new and innovative ideas from outsiders, often to the detriment of its performance. In order to implement OI and achieve its subsequent benefits, the group's free exchange of outside knowledge is an important component of its innovative capabilities (Hagedoorn et al., 2002; Von Krogh et al., 2018).

\section{Employee Attitude towards Internal Knowledge}

Organizations face continuous pressure from the conflict between their inclination to share knowledge with external parties and their tendency to protect their proprietary innovation or intellectual property rights. Employees frequently resist the transition to OI, perceiving it to be a 
threat to their jobs and to traditional models of closed innovation research and development. Consequently, employees' relationships with outside partners become transactional, wherein both parties fail to attain the benefits of OI. It is thus critical to review the ways in which organizations protect their organizational knowledge, while achieving the benefits of OI (Islam, 2012).

H2: Organizations with more open-border cultures will have employees with more positive attitudes, which will increase the likelihood of adoption.

\section{Knowledge Sourcing}

The OI model implies that organizations should use both the inflows and outflows of knowledge in order to not only speed up the creation of internal innovation, but also enrich markets for the external utilization of innovation (Chesbrough, 2006). Within the OI paradigm, there are two dimensions for innovation creation: inbound and outbound (Brunswicker and Vanhaverbeke, 2015). Original ideas come into an organization via the inbound approach whereas, through the outbound approach, ideas and innovations developed inside the organization are attained by external parties with business models that fit the idea or innovation better (Chesbrough, 2003). Large organizations, such as IBM, Xerox, and P\&G, have been moving towards sourcing external knowledge for innovation, rather than depending exclusively on internal research and development programs (R\&D) (Chesbrough, 2003; Dodgson et al., 2006). Knowledge sourcing is a mechanism by which an individual attains knowledge from others (Hervas-Oliver et al., 2019; Gray and Meister, 2004). Likewise, external knowledge sourcing uses external sources of knowledge in a nonpecuniary way and can be considered a dimension of the firm's openness (Brunswicker and Vanhaverbeke, 2015; West and Bogers, 2014). 
Scholarly literature on OI has emphasized the importance of sourcing external knowledge and its role in the firm's inbound OI activities, while external knowledge goes into the organization (Chesbrough et al, 2006; Dahlander and Gann, 2010). More importantly, open innovation proposes that acquiring knowledge and technology in addition to creating partnerships and collaborations promote and expedite innovations (West and Bogers, 2014; Santoro et al., 2018; Ferraris et al., 2020). It has been argued that merging knowledge from different sources could support the creation of disruptive technological outcomes by shifting from current cognitive models and producing technological innovations (Rosenkopf and Nerkar, 2001; Kaplan and Vakili, 2015). In addition to this, knowledge sourcing could introduce new technological paths (Dosi, 1982) that, in turn, may support other organizations in avoiding technological dependency (Kaplan and Vakili, 2015), encourage technological evolution and advancement (Ahuja and Lampert, 2001; Natalicchio et al., 2019), and avoid competency traps through reliance on knowledge generated within the same traditions, procedures, social norms, and principles (Molina-Morales et al., 2015).

Employees' knowledge or technical know-how can be of a great assistance to organizations when evaluating external knowledge and technologies that could be beneficial to acquire and implement (Santoro et al., 2019). Yet, it is important to acquire an external knowledge/technology that fits well with the organization's existing infrastructure. Successfully integrating external knowledge with internal one can enlarge building and commercializing valuable and profitable products and services (Cohen and Levinthal, 1989; Ahn et al., 2016; Ferraris et al., 2018). However, it is important to note that sourcing or obtaining external knowledge may evoke many internal tensions, requiring cultural and human resource management exertion and practices (Vanhaverbeke et al., 2014). As a matter of fact, OI methods generally increase pressure and can result in complicated or unsafe results (de Araújo Burcharth et al., 2014; Del Giudice and Della 
Peruta, 2016). As such, knowledge management and organizational capabilities have been shown to be critical entities when handling a complicated paradigm such as OI (Cohen and Levinthal, 1990; Ahn et al., 2016; Ferraris et al., 2017; Papa et al., 2018; Santoro et al., 2017).

Nevertheless, different external knowledge sourcing approaches have different influences on the firms' innovation performance. For instance, the dependence on the mid-levels of external knowledge created in diverse technological and institutional fields plays an important role in increasing the impact of technological advancements. In fact, excessively great or small levels of openness have an equally negative impact on the effectiveness of organizations' innovative processes. A balanced OI approach is thus recommended (Natalicchio et al., 2019). Research therefore implies that using the proper external knowledge sourcing approach, for either information transfer from informal networks, R\&D collaboration, technological acquisition, or absorptive capacity, is critical to the firm's desired innovation performance (Kang and Kang, 2009; Dabić et al., 2019).

\section{Knowledge Exchange}

The concept of knowledge exchange is used in knowledge management literature to represent the formally organized activity of transferring knowledge from a source to a recipient within the specific boundaries of an organization (Szulanski, 1996; Renzl, 2008). Additionally, in order for the firm to benefit from knowledge sourcing, knowledge exchange must occur. Knowledge exchange is deemed the transfer of knowledge via the collaboration of different parties through connection and exchange, which can allow for mutual learning (Nonaka and Takeuchi, 1995; Argote and Ingram, 2000; Inkpen and Tsang, 2005; Education, 2011). This is considered a requirement for learning and innovation (Lundvall et al., 2002; Powell et al., 1996) and employee diversity in a firm's level of openness (Bogers et al., 2018). Thus, organizations launch 
connections with other organizations through OI in order to innovate and, therefore, OI becomes the exchange of knowledge by the in- and out- flows of knowledge at a firm (Chiang and Hung, 2010; Kuhne et al., 2013; Pirkkalainen et al., 2018; Radziwon and Bogers, 2019).

Generally, knowledge is classified into two categories: tacit and explicit (Hall and Andriani, 2002; Nonaka et al., 2000). Tacit knowledge, which is also known as the 'know-how', is generally uncodified and is often harder to imitate by other organizations as it requires employees to share their experiences with others and to observe and imitate, which gives it a more competitive significance (Kuhne et al., 2013; Hall and Andriani, 2002; Smith, 2001; Hansen et al., 1999). On the other hand, explicit knowledge - or the 'know-what' - is a type of documented and tangible knowledge that is easier to transfer and share between parties (Hall and Andriani, 2002; Nonaka et al., 2000; Smith, 2001). Therefore, to create innovations, firms should use both knowledge types throughout the process (Cowan et al., 2000). The ability to combine knowledge from internal and external sources is important in creating potentially revolutionary technological results (Rosenkopf and Nerkar, 2001; Köhler et al., 2012), refining the organization's innovation performance. Consequently, employees with high levels of knowledge and skills can serve to integrate internal and external knowledge and increase the usefulness of their recombination of both knowledge sources (Gruber et al., 2013), particularly if the organization is implementing an external technology acquisition strategy (Natalicchio et al., 2018).

Furthermore, knowledge exchange includes four main categories: socialization, combination, articulation, and internalization. Different - yet mutually dependent - activities of knowledge exchange occur within the four categories illustrated in the innovation production process (IPP), which consists of three main steps: knowledge accumulation, knowledge transformation, and knowledge exploitation (Roper et al., 2008). Each knowledge exchange 
category has a different significance, depending on the uniqueness of the innovation of interest. For instance, disruptive innovation requires significant knowledge exchange processes to create brand new technologies or business models. Alternatively, incremental innovation requires less significant knowledge exchange processes, as it depends on learning by doing (Kuhne et al., 2013).

\section{Rewards in Open Innovation}

Traditionally, organizations have used incentives such as promotions, pay raises, and performance evaluations to encourage the adoption of new work procedures. In addition, incentive practices have been found to have a critical influence on the relationship between employees' attitudes, their behavioral intentions, and their actual behavior (de Araújo Burcharth et al., 2014; Moeller et al., 2016; Hong et al., 2019). However, although organizational incentive systems have been discussed extensively in psychological and human resource literature (Gagné and Deci, 2005; Ryan and Deci, 2000; Amabile, 1993), little attention has been paid to the study of the design and implementation of incentives in the OI paradigm (Schneckenberg, 2014). In this limited amount of literature, incentive systems have been found to be a critical organizational measure in creating OI cultures (Schneckenberg, 2014; Gassmann et al., 2010; Huizingh, 2011). When adopting open innovation, management should leverage methods such as rewards and training processes for employees and managers who are involved in OI related projects to maximize the influence of the practice (Bogers et al., 2017; Ferraris et al., 2018). However, for organizations adopting an OI model, designing and implementing a strategic incentive system that rewards employees' cooperation with external parties in OI practices is a significant cultural challenge to the adoption

of an OI paradigm (Schneckenberg, 2014; Alexy et al., 2013; Enkel et al., 2009). Thus, from a managerial point of view, understanding the different forms of incentives - and using the most suitable to reward employees' engagement in OI methods - can enhance OI adoption. In addition, 
this understanding can enable firms to incorporate these incentives into a more comprehensive strategic framework in order to foster their OI projects (Schneckenberg, 2014; Dabrowska, et al., 2019). More importantly, a significant strategic purpose of incentive systems is to encourage employees have an open attitude towards OI practices and eliminate the psychological obstacles of NIH syndrome. Dedicating incentive systems for OI delivers a clear message to employees regarding the organization's commitment to moving their corporate culture towards an OI paradigm (Schneckenberg, 2014).

On the other hand, it has been argued that, as OI is a method through which one can attain more efficient innovation, monetary rewards could lead to deceptive attitudes that could harm ideation markets. In fact, many experts have shown that employee recognition is a stronger motivation for employees to participate in OI methods, rather than bonus payments (Schneckenberg, 2014).

H3: Organizations with more open-border cultures will have relevant departments actively participating in knowledge sourcing and knowledge exchange, rewarding Open Innovation activities and thus increasing likelihood of its adoption.

[Insert Figure 1 Here]

\section{DATA, MEASURES, AND METHODS}

Data Source: "Identification of Industrial Needs for Open Innovation Education in Europe" Survey.

The paper uses data from the survey "Identification of Industrial Needs for Open Innovation Education in Europe”, which was conducted by the European Academic Network for Open Innovation (OI-Net) - a three-year project co-funded by the European Commission under the Lifelong Learning Program. The project's objective was to promote the European industry by 
outlining and trading current concepts and feasible applications of OI and OI education, detecting OI educational needs in industrial corporations. It supported the challenge of identifying and classifying the skills and knowledge that managers should acquire when adopting open innovation. The questionnaire was conducted based on a solid theoretical background. The survey contains four main sections. The first section of this survey deals with the current position of OI adoption in the industry. The second section covers the perceived importance (i.e., competencies) of OI within the industry now and in the future. The third section examines the current state of OI knowledge and skills in the industry's employees. Finally, the fourth section covers the required set of OI skills that new graduates need. Data was gathered through an online survey, and the key respondents were from various roles ranging from HR specialists, innovation or R\&D managers, to other specialists in firms that performs open innovation activities. In average, the age of companies was 33 years, while most companies were of a mature age (11-20 years) (Mention, 2017).

The European Academic Network project (OI-Net) surveyed 528 (N=528) employees in 28 different industry sectors from 37 countries. In detail, participants who were involved in this survey were representing 37 countries from Europe, the United States, Brazil, Turkey and China. Also, they were from 28 different industries ranging from energy, education, telecommunication to retailing and transportation. In addition, the survey included participants with a wide range of roles within their companies such as executives, middle managers, owners, and employees, etc., where $32 \%$ of whom have worked at their companies for more than ten years. $44 \%$ of these companies were large, where the rest ranged from medium to small and micro size companies. A comprehensive view of all the participants' demographics is illustrated in Table 5 in appendix. In total, the response rate was between 5 and $7 \%$, depending on the industry and the country. Based 
on the number of answers generated, the sample is considered statistically representative of the population of organizations in these industries and countries.

This paper mainly uses measures from the OI competencies and performance sections of the dataset, which includes the main aspects of the relationship between open-border culture and OI adoption. The size of the analytical sample used in this paper is 520, excluding 8 cases that missed the dependent variable. We used mean/mode imputation to address missing values for independent variables.

\section{Dependent Variable}

Seeing as the main goal of this paper is to study the relationship between organizational culture and OI adoption, the dependent variable of the analysis is the OI adoption status. To understand how organizations that are fully or partially in the process of adopting an OI paradigm are performing in terms of their adoption endeavors, relative to their organizational culture (i.e. open-border or not), we constructed a variable based on respondents' perceptions of their organization's current OI status. The survey question included six different statuses of OI, ranging from not adopting OI, not adopting OI but planning to, in the early stages of OI adoption, in the process of refining and establishing the best OI practices, experienced OI adopters, and discontinued OI. Based on these options, we constructed a dichotomous variable that combines the answers of not adopting OI, not adopting OI but planning to, and discontinued OI as "did not implement OI". Respondents that indicated that their companies are in the early stages of OI adoption, in the process of refining and establishing the best OI practices, or were experienced OI adopters, were coded as "Implemented OI" in order to be able to identify organizations adopting OI and examine whether or not their adoption status was related to their organizational culture. 


\section{Predictor of Interest}

Moreover, the paper's predictor of interest focuses on organizations' open-border culture in order to analyze its relationship with OI adoption in organizations. We wanted to examine organizations that have adopted OI and uncover whether or not the adoption was, in part, a result of the nature of their organizational culture. Organizational culture can either restrain the adoption process or play an important role in enabling employees to be proactive and dynamic in handling adaptative hinderances, simplifying the adoption process. Thus, employees evaluated their organizational culture by answering a question on whether or not the borders of their company were open for knowledge flows from outside-in and from inside-out for OI, using a Likert scale that ranged from 1 to 7 , with 1 indicating if they 'strongly disagree' and 7 indicating 'strongly agree'.

\section{Mediators}

To further deepen the analysis of the relationship between the two main variables, two additional sets of variables were used in this paper as mediators explaining the impact of openborder organization culture on OI adoption in more depth. The first set of mediators included two variables. The first variable measured the degree to which employees held positive attitudes towards applying ideas and technologies from outside their companies. The second variable measured the degree to which employees held positive attitudes towards having other companies receive and use their company's knowledge and technologies. Respondents answered on a Likert scale ranging from 1 to 7 , with 1 indicating 'strongly disagree' and 7 indicating 'strongly agree'.

Furthermore, theses mediators were replaced by two new variables to further examine the effect of open-border organization culture on the adoption of OI. The first variable measured the degree to which relevant departments using OI processes were actively participating in knowledge 
sourcing and knowledge exchange. The second mediator measured the degree to which an organization was rewarding employees who participated in OI activities. Similarly, respondents answered on a Likert scale ranging from 1 to 7 , with 1 indicating 'strongly disagree' and 7 indicating 'strongly agree'.

\section{Control Variable}

Finally, since the firms that participated in the survey were of different sizes - ranging from large, medium, small and micro - the firm's size was considered a controlling variable in this analysis. Firm's size may have an impact on its adoption of OI. Organizations of different sizes have different concentrations and capabilities concerning OI, producing different adoption challenges and stages (Brunswicker and Chesbrough, 2018; Santoro et al., 2018; Naqshbandi et al., 2018). Thus, firm size was controlled in order to provide an unbiased estimate of the correlation between the organization's culture and its OI adoption. The variable was constructed based on the number of employees working for the respondent's company.

\section{[Insert Table 1 Here]}

\section{Analytic Plan}

Descriptive statistics have been provided for all variables used in this research. Logistic regression models were conducted in order to demonstrate how an organization's culture relates to its adoption of OI, and whether or not that relation is partially due to employees' attitudes towards OI practices, active participation of relevant departments in knowledge sourcing and knowledge exchange, and/or rewarding employees for engaging in OI activities. Regression models have been previously used to analyze the impact of culture in an organizational context (Golightly, 2012; Huang, 2013). Therefore, three models will be generated to show these relationships in depth. The first model focuses on the main relationship between an organization's 
culture and its OI adoption. Then, a second model includes the firm size as a control variable to improve the estimation of how organization culture relates to OI adoption in organizations of all sizes. Finally, a third model includes the addition of the two mediating variables. This process was conducted twice; firstly to examine whether employees' positive attitudes explain the relationship between open-border organization culture and OI adoption, and secondly to examine if the active participation of relevant departments in knowledge sourcing and knowledge exchange, in addition to rewarding OI activities, could explain that relationship net of controls (i.e. the net effect of the independent variable, in spite of the control variable). If the coefficient of the organization's culture reduces after adding the mediators to the model, this indicates that these mediators partially explain the reason behind open-border organization's cultural influence on OI adoption.

\section{RESULTS}

\section{[Insert Table 2 Here]}

Table 2 and table 5 in appendix provides descriptive statistics on all of the variables used in the paper. It shows that the proportion of companies that have adopted OI is $32 \%$ of the total sample size. In addition to this, the means measured for open-border organization's culture, employees' positive attitudes toward sharing internal knowledge, and employees' positive attitudes toward receiving external knowledge are 4.46, 4.72, and 4.08 respectively. The means of the active participation of relevant departments in OI activities and the rewarding of OI activities were 4.18 and 3.51. Table 2 and table 5 in appendix shows the proportions of organizations categorized by their sizes, where $44 \%$ of the of organizations in the sample were classified as large, $19 \%$ medium, $19 \%$ small, and $18 \%$ of a micro size.

Table 3 provides odds ratios from logistic regression models predicting the adoption of OI. The baseline model (Model 1) shows that open-border organization culture relates positively to OI 
adoption. More specifically, the first model indicates that a firm's OI adoption increases by $32 \%$ [100(1-1.32)\%] on average with every one-unit increase in the openness of the organization's open-border culture. This relationship is statistically significant $(\mathrm{p}<0.001)$.

Model 2 in Table 3 adds a control for firm size. This model shows that the odds of the firm's OI adoption are 39\% lower on average for medium firms than for larger firms, net of controls. However, this finding is not statically significant $(p=0.067)$. In addition, the odds of the firm's OI adoption are 57\% lower on average for small firms than for larger firms, net of controls. This relationship is statistically significant $(\mathrm{p}=0.003)$. Model 2 illustrates that the odds of the firm's OI adoption are 56\% lower on average for medium firms than for larger firms, net of controls, which is also statistically significant $(\mathrm{p}=0.004)$. Nevertheless, in Model 2, the openborder organization's cultural relationship with OI adoption was still positive. In fact, the coefficient was seen to increase in comparison to Model 1. The odds of a firm's OI adoption increases, therefore, by $38 \%$ with every one-unit increase in the openness of the organization's cultural border level, net of controls. This relation is statistically significant $(\mathrm{p}<0.001)$.

Model 3 in Table 3 incorporates two mediating variables to study their role in explaining the relationship between open-border organization culture and OI adoption in firms. The first mediator included in this model is employees' positive attitude levels towards receiving external knowledge. The logistic regression in this model shows that the odds of adopting OI increase by $3 \%$ for every one-unit increase in employees' positive attitude level towards receiving external knowledge, net of controls. However, this relationship is not statistically significant ( $p=0.721)$. On the other hand, the model included employees' positive attitude levels towards sharing internal knowledge as a second mediating variable. The results show that the odds of adopting OI increase by $11 \%$ with every one-unit increase in employees' positive attitude levels towards sharing internal 
knowledge, net of controls. This relationship was not statistically significant $(\mathrm{p}=0.124)$. Adding the two mediators to the logistic regression have contributed to the decrease of the open-border organizational culture coefficient, wherein the odds of the firm's OI adoption increase by $31 \%$ (compared to $38 \%$ in Model 2, without the mediators) for every one-unit increase in the openness of the organization's cultural border level, net of controls. This proposes that employees' positive attitudes towards receiving external knowledge and sharing internal knowledge are mediators in the relationship between open-border organization culture and OI adoption in firms, and thus partially explain it. This relationship is statistically significant $(\mathrm{p}<0.001)$.

\section{[Insert Table 3 Here]}

For the second part of the research, Models 1 and 2 in Table 4 show similar results to Models 1 and 2 in Table 3, as the same variables were used. However, in Model 3 in Table 4 (b) two new mediating variables were employed to study their role in explaining the relationship between open-border organizational cultures and OI adoption in firms. The first mediator included in this model was OI relative departments' active participation in knowledge sourcing and knowledge exchange. By adding employees' participation in knowledge sharing practices as a mediator to explain the relationship between open-border cultures and OI adoption, we found that the logistic regression of this model showed that the odds of a firm's OI adoption increased by $31 \%$ for every one-unit increase in employees' active participation in knowledge sourcing and knowledge exchange practices, net of controls. This relationship is statistically significant $(\mathrm{p}<$

0.001). Furthermore, the model included rewarding employees who participated in OI activities as a second mediating variable. The results showed that the odds of the firm's OI adoption increase by $24 \%$ for every one-unit increase in rewarding employees who participate in OI activities, net of controls. This relationship is statistically significant $(\mathrm{p}<0.001)$. Similar to Model 3, in Table 4, 
adding the two mediators - employees' knowledge and rewards - to the logistic regression contributed to the decrease of the open-border organization culture coefficient, yet the decrease was more significant this time: the odds of the firm's OI adoption increased by $14 \%$ (compared to $38 \%$ in Model 2, without the mediators) for every one-unit increase in the openness of the organization's cultural border level, net of controls. These results suggest that employees' participation in knowledge sourcing and knowledge exchange practices, as well as rewarding OI activities, can be considered mediators in the relationship between open-border organization culture and OI adoption in firms, and they explain this relationship to some extent. This relationship is statistically significant $(\mathrm{p}<0.05)$.

\section{[Insert Table 4 Here]}

\section{DISCUSSION AND CONCLUSIONS}

This paper aims to empirically analyze the impact of antecedents and mediators, such as organizational culture, employees' attitudes and knowledge, and rewards on the adoption of an OI paradigm within organizations. More importantly, it empirically studies these factors together, keeping in mind their nested nature using a multi-level analysis. As a foundation for this study, a conceptual model that was formed based on existing academic literature on OI was developed. Accordingly, three hypotheses have been proposed and tested applying logistic regression models using a sample that included 528 employees.

The results of this paper, to some extent, are consistent with what has been proposed in extant OI literature (Boschma, 2005; Carbone et al., 2010; Lichtenthaler, 2011; Van de Vrande et al., 2009; Barham et al., 2020), as thy depict organizational culture as an important factor that challenges OI adoption. The paper's baseline hypothesis confirms the statistically significant impact of the organization's culture on OI adoption. The results strongly support the baseline 
hypothesis, confirming that open organization cultures relate positively with OI adoption (Tirabeni and Soderquist, 2019; Vlajcic et al., 2019). A valuable organizational culture eases the adoption process by enabling the organization to identify dynamically changing problems in adoption, including external and internal organizational resource integration, employees, and rules to support external adoption (Pool, 2000); simplify the OI adoption process (Van de Vrande et al., 2009); and make external collaborations effective (Boschma, 2005). In particular, this finding empirically confirms the importance of a coupled process of OI as one possible category of an open-border culture. In the coupled process, both external and internal knowledge processes are employed to facilitate the adoption of the OI paradigm and enhance the innovativeness of the organization (Tirabeni and Soderquist, 2019; Vlajcic et al., 2019). In addition, these findings confirm the assessment of culture's perception as a possible barrier to the open approach that OI consists of (Golightly et al., 2012; Naqshbandi, 2015). Thus, we can say that companies with an open-border culture that values and uses knowledge from internal and external sources have a better chance of adopting OI.

More importantly, looking at the focal points of this paper, this research not only presents an empirical analysis of organizational factors that impact upon OI adoption, but also studies the mediating effect of these factors, addressing both the firm and the individual level as units of analysis. The results show that employees' knowledge and rewards strengthen the positive effect of the open-border organization's culture on the adoption of OI and mediate this relationship. In fact, the findings were statically significant, thus supporting the hypothesis, which argues that the more open-border the organizational culture is, the more employees will actively participate in knowledge sourcing and exchange and be rewarded for OI activities. This hypothesis employs a multi-level analysis, in which it looks at factors at an organizational level - in terms of 
organizational culture - in addition to an individual level represented by employees' participation in knowledge processes, enabling a deeper understanding of how open-border cultures increase the likelihood of the OI adoption in a firm. They demonstrate that employees' active engagement in knowledge sourcing and exchange processes influence the openness of the culture which, in turn, increases the likelihood of OI adoption.

This paper addresses the relative absence of emphasis on the individual characteristics of the OI paradigm. More importantly, the relative lack of focus on analyzing these factors as antecedents impacting the OI adoption in an organization. The results show that employees are a key anteceding factor to this process. The organization's OI adoption is related to employees' acceptance and engagement in knowledge sourcing and exchange. Hence, employees' resistance to use external knowledge and their absence of commitment to internal knowledge will create a problematic culture that will weaken the adoption of OI practices.

The results have also confirmed variations in OI adoption based on the organization's size, demonstrating a lower likelihood for small and micro organizations to adopt OI in comparison to large organizations. Mainly, the variance in OI adoption can be attributed to the range of available resources that large organizations have and can leverage compared to the limited capabilities that small and micro organizations have. On the other hand, the results failed to support the second hypothesis, which claims that the more open-border the organizational culture is, the more positive its employees' attitudes will be towards knowledge. Although employees' attitudes towards receiving external knowledge and sharing internal knowledge have contributed to explaining the impact of open-border organization cultures as a factor of OI adoption, it was not significant enough to support the hypothesis and confirm the relationship. 
Linked to the above results, we developed several proposed implications. Firstly, the results of this paper demonstrate the anteceding impact of organizational culture along with employees' knowledge and attitudes on OI adoption, accounting for a mediating effect. The analysis of this study could guide managers through major organizational changes, such as the adoption of an OI paradigm. Hence, the findings of this paper could help practitioners to nurture certain types of organization culture that enable OI adoption and avoid those that hinder the process. An understanding of the findings can also help firms predict, based on their current organizational culture, whether or not they should embark on an OI journey or first ensure that their organizational culture is conducive for the OI model. The organization's future relies on its manager's skill to control a permeating, persistent, and permanent condition that follow up every changes in organization (Ivancevich et al., 2008). Managers recognize the significance of organizational change, yet most of them fail to implement it effectively (Rosenberg and Mosca, 2011). Thus, by taking these findings into consideration, managers can avoid the unfavorable consequences of a failed attempt at OI adoption. On the other hand, for organizations planning to adopt the OI paradigm, identifying the positive impact of organizational culture on OI adoption could encourage managers to veer their organizations towards an open-border culture. As managers anticipate barriers to adoption, they can implement strategies to diminish their affect or avoid them completely. More importantly, the findings have shown a positive impact of employees' knowledge on the adoption of OI, with respect to the organization's culture. Understanding the role of knowledge in supporting the competitive strategies of organizations (i.e. adopting an OI paradigm), increases the need for managers to create suitable knowledge management practices in order to effectively encrypt, store, share, diffuse, and leverage employees' knowledge assets (Alavi and Leidner, 2001). Suitable knowledge management activities may advance the organization's 
innovative performance (Alegre et al., 2011; Darroch, 2005; Natalicchio et al., 2017). Furthermore, the understanding of the level of impact that the factors at an individual level have on OI adoption, with respect to the organization's culture, can assist managers in anticipating challenges associated with OI strategies, such as employee resistance and NIH syndrome. Employee resistance could be acknowledged as a significant source of employee feedback, advancing the quality and clarity of the organization's goals and strategies when a change is properly offered, which can increase the chances of a successful change implementation (Ford and Ford, 2009). Finally, bearing in mind the positive impact of an incentive system for OI activities, as shown in the results, managers can strategically use rewards to enable employees to have an open attitude towards OI practices and eliminate the psychological obstacles of NIH syndrome. Dedicated incentive systems for OI will prove to employees the organization's commitment to moving their corporate culture towards an OI paradigm (Schneckenberg, 2014). Overall, this study's findings stress that organizations' management need to be conscious of the importance of the organization's culture and employees' knowledge participation in the organizational change of adopting OI. They need to recognize the increasing trend towards OI as a competitive strategy and, if they fail to respond, they will stand at a competitive disadvantage. According to Gentile (2019) top management plays a vital role in creating an innovation-friendly environment that encourages the search for knowledge from external sources. Certainly, the adoption of an OI paradigm can be perceived as a variation from the current innovation routine (Ahn et al. 2017) which can create resistance and disinterest from the firm's employees. This arises the importance of the role of managers in fostering the adoption of open innovation new knowledge, processes, and structures, where it has been proven that their support encourages OI adoption and aids in diminishing resistance (Huston and Sakkab 2006; Chiaroni et al. 2011; Ceci and Iubatti 2012). 
This paper contributes to the growing body of literature by filling the gap in OI theory (Lichtenthaler, 2011) by empirically examining the relationship between OI adoption and its anteceding factors, such as organizational culture with respect to employees' knowledge, attitudes, and rewards. It offers a possible explanation as to why open-border cultures are more likely to adopt OI, by relating it to factors that advance the presence of an open-border culture, such as employees' active participation in knowledge sourcing and knowledge exchange practices, and rewarding employees for OI activities. Few studies of OI antecedents, especially on individuals and culture, have been introduced in OI literature (Bogers et al., 2017; Durst and Ståhle, 2013). Thus, this study's findings are valuable and critical to understanding the factors that impact upon OI adoption, developing informative strategies that handle adoption threats efficiently.

Furthermore, an important contribution of this study is that it applies a multi-level analysis in order to advance the theoretical concept by dividing the concept into several elements and then drawing the relationships between them at diverse levels of analysis. This approach advances our understanding of OI, especially in that it addresses both the firm and the individual as units of analysis. A call for a multi-level perspective investigation was proposed in existing academic literature, in order to grasp a better understanding of the antecedents and outcomes of OI (Gassmann et al., 2010: 218; Salvato and Rerup, 2011; West et al., 2014). As such, this paper was developed as a response for that need. More importantly, it accounts for and tests the mediating effect of some factors critical to the adoption process, such as employees' knowledge, attitudes, and rewards. The results show a positive relationship between open-border cultures and OI adoption. However, this conclusion is not valuable unless we understand what factors encourage the organizational culture to be open-border, and accordingly have a higher likelihood of adopting 
a beneficial paradigm - such as OI. This is important because it highlights the critical role of employees' knowledge during an organizational change phase.

Moreover, this paper sheds light on an anteceding factor that has proved to have a positive impact on OI adoption, yet this factor has received little attention in literature when it comes to studying its role in an OI paradigm (Schneckenberg, 2014). This study shows that the organizational culture relates positively to OI adoption when accounting for OI activities being rewarded. This opposes what has been argued in scholarly literature: the notion that monetary rewards could lead to a deceptive attitude that harms the ideation markets and favors employee recognition as a better alternative to motivate employees to participate in OI methods (Schneckenberg, 2014). This paper confirms the positive role of incentive systems on the adoption of OI.

A possible limitation of this paper is the potential bias in analysis caused by the high variance in the number of organizations that were considered large (more than 44\%) in comparison to medium, small, and micro organizations. The size could also influence the age of the organization, as medium, small, and micro organizations tend to be younger in comparison to large organizations. This variation could impact upon an organization's mindset and meddle between the open-border culture relationship with OI adoption. In addition to this, as the dataset that formed the basis of this paper was generated in European countries, the results of the analysis are limited and appropriate for this region and may vary when applied to other regions of the world.

This finding proposes a basis for future research on this subject, wherein it could be further developed with an expanded analysis. Future research could utilize our multi-level analysis approach in order to explore the impact of additional organizational factors that impact upon OI adoption. The more we know about this paradigm, the better and more effective its trend will be. 
Furthermore, a moderated multi-mediation analytical approach can be also used to further expand the analysis of this study. Such model can enhance the understanding of complex interrelationships as what is in between the OI antecedents (Rialti et al., 2019). We also propose further researchers attempt to expand and generalize the paper's findings by looking at the relationship between organizational characteristics (i.e. open-border culture and employees' positive attitudes toward internal and external knowledge, active knowledge sourcing and exchange, and rewards) and OI adoption through a global lens, including data from companies from different parts of the world instead of one region. Future research could also explore these relationships by segmenting an industry or a specific firm size (i.e. SMEs) and investigate whether or not the impact of these variables act differently from the general data results. 


\section{REFRENCES}

Ahn, J. M., Ju, Y., Moon, T. H., Minshall, T., Probert, D., Sohn, S. Y., \& Mortara, L. (2016). Beyond absorptive capacity in open innovation process: the relationships between openness, capacities and firm performance. Technology Analysis \& Strategic Management, 28(9), 10091028 .

Ahn, J. M., Roijakkers, N., Fini, R., \& Mortara, L. (2019). Leveraging open innovation to improve society: past achievements and future trajectories. R\&D Management, 49(3), 267-278.

Ahuja, G., \& Morris Lampert, C. (2001). Entrepreneurship in the large corporation: A longitudinal study of how established firms create breakthrough inventions. Strategic management journal, 22(6-7), 521-543.

Alavi, M., \& Leidner, D. E. (2001). Knowledge management and knowledge management systems: Conceptual foundations and research issues. MIS quarterly, 107-136.

Alegre, J., Sengupta, K., \& Lapiedra, R. (2013). Knowledge management and innovation performance in a high-tech SMEs industry. International Small Business Journal, 31(4), 454-470.

Alexy, O., George, G., \& Salter, A. J. (2013). Cui bono? The selective revealing of knowledge and its implications for innovative activity. Academy of management review, 38(2), 270-291.

Amabile, T. M. (1993). Motivational synergy: Toward new conceptualizations of intrinsic and extrinsic motivation in the workplace. Human resource management review, 3(3), 185-201.

Argote, L., \& Ingram, P. (2000). Knowledge transfer: A basis for competitive advantage in firms. Organizational behavior and human decision processes, 82(1), 150-169.

Barham, H., Shifrer, D., Dabic, M., Daim, T. (2020) A Quantitative Analysis of the Influence of Firms' Management Support on Open Innovation Adoption, Technology in Society in press doi.org/10.1016/j.techsoc.2020.101282

Bogers, M., Chesbrough, H. W. \& Moedas, C. (2018) Open innovation: research, practices, and policies. California Management Review, 60(2), 5-16.

Bogers, M., Foss, N. J., \& Lyngsie, J. (2018). The "human side" of open innovation: The role of employee diversity in firm-level openness. Research Policy, 47(1), 218-231.

Bogers, M., Zobel, A. K., Afuah, A., Almirall, E., Brunswicker, S., Dahlander, L. \& Hagedoorn, J. (2017). The open innovation research landscape: Established perspectives and emerging themes across different levels of analysis. Industry and Innovation, 24(1), 8-40.

Bonfanti, A., Del Giudice, M., \& Papa, A. (2018). Italian craft firms between digital manufacturing, open innovation, and servitization. Journal of the Knowledge Economy, 9(1), 136-149.

Boschma, R. (2005). Proximity and innovation: a critical assessment. Regional studies, 39(1), 6174.

Brunswicker, S., \& Chesbrough, H. (2018). The Adoption of Open Innovation in Large Firms: Practices, Measures, and Risks A survey of large firms examines how firms approach open innovation strategically and manage knowledge flows at the project level. Research-Technology Management, 61(1), 35-45. 
Brunswicker, S., \& Vanhaverbeke, W. (2015). Open innovation in small and medium-sized enterprises (SMEs): External knowledge sourcing strategies and internal organizational facilitators. Journal of Small Business Management, 53(4), 1241-1263.

Büschgens, T., Bausch, A., \& Balkin, D. B. (2013). Organizational culture and innovation: A metaanalytic review. Journal of product innovation management, 30(4), 763-781.

Canik, Y., bohemia, E. and Telalbasic, I., 2017. Mapping coupled open innovation processes from Activity Theory framework. IN: Bohemia, E., de Bont, C. and Svengren Holm, L. (eds.) Proceedings of the Design Management Academy 2017 Hong Kong: Research Perspectives on Creative Intersections. Hong Kong, 7-9 June 2017.

Carbone, F., Contreras, J., \& Hernandez, J. (2010). Enterprise 2.0 and semantic technologies: A technological framework for open innovation support. In Proceedings of the 11th European Conference on Knowledge Management (Vol. 1, pp. 191-199).

Ceci, F., \& Iubatti, D. (2012). Personal relationships and innovation diffusion in SMEs networks: a content analysis approach. Research Policy, 41, 565-579.

Chen, H., Zeng, S., Yu, B., \& Xue, H. (2019). Complementarity in open innovation and corporate strategy: The moderating effect of ownership and location strategies. IEEE Transactions on Engineering Management. 10.1109/TEM.2018.2889804

Chesbrough, H. W. (2003). Open innovation: The new imperative for creating and profiting from technology. Harvard Business Press.

Chesbrough, H. (2004). Managing open innovation. Research-Technology Management, 47(1), 2326.

Chesbrough, H. (2006). Open innovation: a new paradigm for understanding industrial innovation. Open innovation: Researching a new paradigm, 400, 0-19.

Chesbrough, H. (2006). Open business models: How to thrive in the innovation landscape. Harvard Business Press.

Chesbrough, H. W. (2006). Open innovation: The New Imperative for Creating and Profiting from Technology. Brighton, MA: Harvard Business Press.

Chesbrough, H. W., W. Vanhaverbeke, and J. West (Eds.) (2006). Open Innovation: Researching a New Paradigm. Oxford: Oxford University Press.

Chesbrough, H., \& Crowther, A. K. (2006). Beyond high tech: early adopters of open innovation in other industries. $R \& d$ Management, 36(3), 229-236.

Chesbrough, H., Vanhaverbeke, W., \& West, J. (Eds.). (2014). New frontiers in open innovation. Oup Oxford.

Chesbrough, H., Vanhaverbeke, W., Bakici, T., \& Lopez-Vega, H. (2011). Open innovation and public policy in Europe. Science Business Publishing Ltd.1181-1198.

Chiang, Y. H., \& Hung, K. P. (2010). Exploring open search strategies and perceived innovation performance from the perspective of inter-organizational knowledge flows. $R \& d$ Management, 40(3), 292-299. 
Chiaroni, D., Chiesa, V. and Frattini, F., (2011). The Open Innovation Journey: How firms dynamically implement the emerging innovation management paradigm. Technovation, 31(1), pp.34-43.

Cohen, W. M., \& Levinthal, D. A. (1989). Innovation and learning: the two faces of R \& D. The economic journal, 99(397), 569-596.

Cohen, W. M., \& Levinthal, D. A. (1990). Absorptive capacity: A new perspective on learning and innovation. Administrative science quarterly, 35(1), 128-152.

Cowan, R., David, P. A., \& Foray, D. (2000). The explicit economics of knowledge codification and tacitness. Industrial and corporate change, 9(2), 211-253.

Dabić, M., Vlačić, E., Ramanathan, U., \& Egri, C. P. (2019). Evolving Absorptive Capacity: The Mediating Role of Systematic Knowledge Management. IEEE Transactions on Engineering Management. DOI: 10.1109/TEM.2019.2893133

Dabrowska, J. (2015). Report on Industrial Needs for Open Innovation Education. OI-Net.

Dabrowska, J., Lopez-Vega, H., \& Ritala, P. (2019). Waking the sleeping beauty: Swarovski's open innovation journey. $R \& D$ Management. https://doi.org/10.1111/radm.12374

Dahlander, L., \& Gann, D. M. (2010). How open is innovation?. Research policy, 39(6), 699-709.

Darroch, J. (2005). Knowledge management, innovation and firm performance. Journal of knowledge management.

de Araújo Burcharth, A. L., Knudsen, M. P., \& Søndergaard, H. A. (2014). Neither invented nor shared here: The impact and management of attitudes for the adoption of open innovation practices. Technovation, 34(3), 149-161.

Del Giudice, M., \& Della Peruta, M. R. (2016). The impact of IT-based knowledge management systems on internal venturing and innovation: a structural equation modeling approach to corporate performance. Journal of Knowledge Management. 20(3), 484-498

https://doi.org/10.1108/JKM-07-2015-0257

Denison, D. R., \& Mishra, A. K. (1995). Toward a theory of organizational culture and effectiveness. Organization science, 6(2), 204-223.

Dodgson, M., Gann, D., \& Salter, A. (2006). The role of technology in the shift towards open innovation: the case of Procter \& Gamble. $R \& D$ Management, 36(3), 333-346.

Dosi, G. (1982). Technological paradigms and technological trajectories. Research policy, 2(3), I47-62.

Durst, S., \& Ståhle, P. (2013). Success factors of open innovation-a literature review. International Journal of Business Research and Management, 4(4), 111-131.

Education, R. S. P. i. (2011) Knowledge Mobilization: terms and definitions. Retrieved from http://www.oise.utoronto.ca/rspe/KM_Products/Terminology/index.html.

Enkel, E., Oliver, G., \& Chesbrough H. W. (2009). Open R\&D and open innovation: exploring the phenomenon. $R \& D$ Management. 39(4), 311-316. 
Expósito, A., Fernández-Serrano, J., \& Liñán, F. (2019). The impact of open innovation on SMEs' innovation outcomes. Journal of Organizational Change Management. https://doi.org/10.1108/JOCM-09-2018-0253

Fakhar Manesh, M., Pellegrini, M. M., Marzi, G., \& Dabic, M. (2020). Knowledge Management in the Fourth Industrial Revolution: Mapping the Literature and Scoping Future Avenues. IEEE Transactions on Engineering Management. https://doi.org/10.1109/TEM.2019.2963489

Ferraris, A., Santoro, G., \& Dezi, L. (2017). How MNC's subsidiaries may improve their innovative performance? The role of external sources and knowledge management capabilities. Journal of Knowledge Management.

Ferraris, A., Santoro, G., \& Pellicelli, A. C. (2020). "Openness" of public governments in smart cities: removing the barriers for innovation and entrepreneurship. International Entrepreneurship and Management Journal, 1-22.

Fini, R., Rasmussen, E., Siegel, D., \& Wiklund, J. (2018). Rethinking the commercialization of public science: From entrepreneurial outcomes to societal impacts. Academy of Management Perspectives, 32(1), 4-20.

Ford, JD \& Ford, LW (2009). Decoding Resistance to Change. Harvard Business Review. 01-08.

Gagné, M., \& Deci, E. L. (2005). Self-determination theory and work motivation. Journal of Organizational behavior, 26(4), 331-362.

Gassmann, O., Enkel, E., \& Chesbrough, H. (2010). The future of open innovation. $R \& D$ Management, 40(3), 213-221.

Gentile-Lüdecke, S., de Oliveira, R. T., \& Paul, J. (2019). Does organizational structure facilitate inbound and outbound open innovation in SMEs?. Small Business Economics, 1-22.

Golightly, J., Ford, C., Sureka, P., \& Reid, B. (2012). Realising the value of open innovation. Big Innovation Centre (The Work Foundation and Lancaster University), London.

Gray, P. H., \& Meister, D. B. (2004). Knowledge Sourcing Effectiveness. Management Science, 50(6), 821-834.

Gruber, M., Harhoff, D., \& Hoisl, K. (2013). Knowledge recombination across technological boundaries: Scientists vs. engineers. Management Science, 59(4), 837-851.

Gupta, A. K., Tesluk, P. E., \& Taylor, M. S. (2007). Innovation at and across multiple levels of analysis. Organization science, 18(6), 885-897.

Hagedoorn, John, and Geert Duysters (2002). External sources of innovative capabilities: the preferences for strategic alliances or mergers and acquisitions. Journal of management studies 39, no. 2: 167-188.

Hall, R., \& Andriani, P. (2002). Managing knowledge for innovation. Long range planning, 35(1), $29-48$.

Hansen, M. T., Nohria, N., \& Tierney, T. (1999). What's your strategy for managing knowledge. The knowledge management yearbook 2000-2001, 77(2), 106-116.

Harison, E., \& Koski, H. (2010). Applying open innovation in business strategies: Evidence from Finnish software firms. Research Policy, 39(3), 351-359. 
Hervas-Oliver, J. L., Sempere-Ripoll, F., Boronat-Moll, C., \& Estelles-Miguel, S. (2019). SME open innovation for process development: Understanding process-dedicated external knowledge sourcing. Journal of Small Business Management, 1-37. DOI: 10.1080/00472778.2019.1680072

Hoffmann, W. H., \& Schlosser, R. (2001). Success factors of strategic alliances in small and medium-sized enterprises-An empirical survey. Long range planning, 34(3), 357-381.

Hong, J. F., Zhao, X., \& Stanley Snell, R. (2019). Collaborative-based HRM practices and open innovation: a conceptual review. The International Journal of Human Resource Management, 30(1), 31-62.

Huston, L., \& Sakkab, L. (2006). Connect and develop: inside Procter \& Gamble's new model for innovation. Harvard Business Review, 84, 58-66.

Huang, F., \& Rice, J. (2013). Does open innovation work better in regional clusters?. Australasian Journal of Regional Studies, The, 19(1), 85.

Huizingh, E. K. (2011). Open innovation: State of the art and future perspectives. Technovation, 31(1), 2-9.

Inkpen, A. C., \& Tsang, E. W. (2005). Social capital, networks, and knowledge transfer. Academy of management review, 30(1), 146-165.

Islam, A. M. (2012). Methods of Open Innovation Knowledge Sharing RiskReduction: A Case Study. International Journal of e-Education, e-Business, e-Management and e-Learning, 2(4), 294.

Ivancevich, John M \& Konopaske, Robert \& Matteson, Michael T (2008). Organizational behavior and management (8th ed). McGraw-Hill/Irwin, a business unit of The McGraw-Hill Companies, Inc, Boston

Kang, K. H., \& Kang, J. (2009). How do firms source external knowledge for innovation? Analysing effects of different knowledge sourcing methods. International Journal of Innovation Management, 13(01), 1-17.

Kaplan, S., \& Vakili, K. (2015). The double-edged sword of recombination in breakthrough innovation. Strategic Management Journal, 36(10), 1435-1457.

Katz, R., \& Allen, T. J. (1982). Investigating the Not Invented Here (NIH) syndrome: A look at the performance, tenure, and communication patterns of $50 \mathrm{R} \& \mathrm{D}$ Project Groups. $R \& D$ Management, 12(1), 7-20.

Köhler, C., Sofka, W., \& Grimpe, C. (2012). Selective search, sectoral patterns, and the impact on product innovation performance. Research Policy, 41(8), 1344-1356.

Kuhne, B., Lefebvre, V. M., \& Gellynck, X. (2013). Knowledge exchange in innovation networks: How networks support open innovation in food SMEs (No. 1021-2016-81800, pp. 181-196).

Laursen, K., \& Salter, A. (2006). Open for innovation: the role of openness in explaining innovation performance among UK manufacturing firms. Strategic management journal, 27(2), 131-150.

Lettl, C., Herstatt, C., \& Gemuenden, H. G. (2006). Users' contributions to radical innovation: evidence from four cases in the field of medical equipment technology. $R \& D$ Management, 36(3), 251-272. 
Lichtenthaler, U. (2011). Open innovation: Past research, current debates, and future directions. Academy of management perspectives, 25(1), 75-93.

Lichtenthaler, U., \& Lichtenthaler, E. (2009). A capability-based framework for open innovation: Complementing absorptive capacity. Journal of management studies, 46(8), 1315-1338.

Lin, F., \& Evans, R., Kharel, R., \& Williams, R. (2019). Competitive Intelligence and Product Innovativeness: The Role of Open-Mindedness and Inter-Functional Coordination. IEEE Transactions on Engineering Management. 10.1109/TEM.2019.2943359.

Lundvall, B. Å., Johnson, B., Andersen, E. S., \& Dalum, B. (2002). National systems of production, innovation and competence building. Research policy, 31(2), 213-231.

Mention, A.L., Nagel, A., Hafkesbrink, J. and Dabrowska, J. (2017), Innovation Education Reloaded: Nurturing Skills for the Future, The Open Innovation Handbook, LUT, Lappeenranta.

Michie, J., \& Sheehan, M. (2003). Labour market deregulation, 'flexibility' and innovation. Cambridge journal of economics, 27(1), 123-143.

Moeller, M., Maley, J., Harvey, M., \& Dabic, M. (2016). People management and innovation in emerging market multinationals: A competency-based framework. Journal of Management development, 35(4), 530-548.

Mohr, J., \& Spekman, R. (1994). Characteristics of partnership success: partnership attributes, communication behavior, and conflict resolution techniques. Strategic Management Journal, 15(2), 135-152.

Molina-Morales, F. X., Belso-Martínez, J. A., Más-Verdú, F., \& Martínez-Cháfer, L. (2015). Formation and dissolution of inter-firm linkages in lengthy and stable networks in clusters. Journal of Business Research, 68(7), 1557-1562.

Mortara, L., \& Minshall, T. (2011). How do large multinational companies implement open innovation?. Technovation, 31(10-11), 586-597.

Muffatto, M. (1998). Corporate and individual competences: how do they match the innovation process?. International journal of technology management, 15(8), 836-853.

Nakagaki, P., Aber, J., \& Fetterhoff, T. (2012). The challenges in implementing open innovation in a global innovation-driven corporation. Research-Technology Management, 55(4), 32-38.

Naqshbandi, M. M., \& Jasimuddin, S. M. (2018). Knowledge-oriented leadership and open innovation: Role of knowledge management capability in France-based multinationals. International Business Review, 27(3), 701-713.

Naqshbandi, M. M., Kaur, S., \& Ma, P. (2015). What organizational culture types enable and retard open innovation?. Quality \& Quantity, 49(5), 2123-2144.

Natalicchio, A., Ardito, L., Messeni Petruzzelli, A., \& Del Giudice, M. (2019). The origins of external knowledge inflows and the impact of university technologies. R\&D Management, 49(4), 639-651.

Natalicchio, A., Ardito, L., Savino, T., \& Albino, V. (2017). Managing knowledge assets for open innovation: a systematic literature review. Journal of Knowledge Management. 
Natalicchio, A., Petruzzelli, A. M., Cardinali, S., \& Savino, T. (2018). Open innovation and the human resource dimension. Management Decision 56(6),1271-1284.

Nonaka, I., \& Takeuchi, H. (1995). The knowledge-creating company: How Japanese companies create the dynamics of innovation. Oxford university press.

Nonaka, I., Toyama, R., \& Konno, N. (2000). SECI, Ba and leadership: a unified model of dynamic knowledge creation. Long range planning, 33(1), 5-34.

Open Innovation [Google Scholar]. (n.d.). Retrieved January 31, 2020, from https://www.scholar.google.com/scholar?hl=en\&as_sdt=0\%2C38\&q=open+innovation+\&bt $\mathrm{nG}=$

Papa, A., Dezi, L., Gregori, G. L., Mueller, J., \& Miglietta, N. (2018). Improving innovation performance through knowledge acquisition: the moderating role of employee retention and human resource management practices. Journal of Knowledge Management.

Pfotenhauer, S. M., Juhl, J., \& Aarden, E. (2019). Challenging the "deficit model" of innovation: Framing policy issues under the innovation imperative. Research Policy, 48(4), 895-904.

Piller, F. T., \& Walcher, D. (2006). Toolkits for idea competitions: a novel method to integrate users in new product development. $R \& d$ Management, 36(3), 307-318.

Pirkkalainen, H., Pawlowski, J. M., Bick, M., \& Tannhäuser, A. C. (2018). Engaging in knowledge exchange: The instrumental psychological ownership in open innovation communities. International Journal of Information Management, 38(1), 277-287.

Pool, S. W. (2000). Organizational culture and its relationship between job tension in measuring outcomes among business executives. Journal of management development, 19(1), 32-49.

Popa, S., Soto-Acosta, P., \& Martinez-Conesa, I. (2017). Antecedents, moderators, and outcomes of innovation climate and open innovation: An empirical study in SMEs. Technological Forecasting and Social Change, 118, 134-142.

Powell, W. W., Koput, K. W., \& Smith-Doerr, L. (1996). Interorganizational collaboration and the locus of innovation: Networks of learning in biotechnology. Administrative science quarterly, 116145 .

Radziwon, A., \& Bogers, M. (2019). Open innovation in SMEs: Exploring inter-organizational relationships in an ecosystem. Technological Forecasting and Social Change, 146, 573-587.

Rialti, R., Zollo, L., Ferraris, A., \& Alon, I. (2019). Big data analytics capabilities and performance: Evidence from a moderated multi-mediation model. Technological Forecasting and Social Change, 149, 119781.

Roper, S., Du, J., \& Love, J. H. (2008). Modelling the innovation value chain. Research policy, 37(6-7), 961-977.

Rosenberg, S., \& Mosca, J. (2011). Breaking down the barriers to organizational change. International Journal of Management \& Information Systems (IJMIS), 15(3), 139-146.

Rosenkopf, L., \& Nerkar, A. (2001). Beyond local search: boundary-spanning, exploration, and impact in the optical disk industry. Strategic management journal, 22(4), 287-306. 
Ryan, R. M., \& Deci, E. L. (2000). Intrinsic and extrinsic motivations: Classic definitions and new directions. Contemporary educational psychology, 25(1), 54-67.

Salter, A., Criscuolo, P., \& Ter Wal, A. L. (2014). Coping with open innovation: responding to the challenges of external engagement in R\&D. California Management Review, 56(2), 77-94.

Salvato, C., \& Rerup, C. (2011). Beyond collective entities: Multilevel research on organizational routines and capabilities. Journal of management, 37(2), 468-490.

Santoro, G., Ferraris, A., \& Winteler, D. J. (2019). Open innovation practices and related internal dynamics: case studies of Italian ICT SMEs. EuroMed Journal of Business. 14(1): 47-61

Santoro, G., Ferraris, A., Giacosa, E., \& Giovando, G. (2018). How SMEs engage in open innovation: a survey. Journal of the Knowledge Economy, 9(2), 561-574.

Santoro, G., Bresciani, S., \& Papa, A. (2018). Collaborative modes with cultural and creative industries and innovation performance: The moderating role of heterogeneous sources of knowledge and absorptive capacity. Technovation. 92-93,

DOI: $10.1016 /$ j.technovation.2018.06.003

Santoro, G., Vrontis, D., \& Pastore, A. (2017). External knowledge sourcing and new product development. British Food Journal.

Schneckenberg, D. (2014). Strategic incentive systems for open innovation. Journal of Applied Business Research (JABR), 30(1), 65-72.

Singh, S. K., Gupta, S., Busso, D., \& Kamboj, S. (2019). Top management knowledge value, knowledge sharing practices, open innovation and organizational performance. Journal of Business Research. https://doi.org/10.1016/j.jbusres.2019.04.040

Smith, E. A. (2001). The role of tacit and explicit knowledge in the workplace. Journal of knowledge Management, 5(4), 311-321.

Švarc, J., \& Dabić, M. (2019). The Croatian path from socialism to European membership through the lens of technology transfer policies. The Journal of Technology Transfer, 44(5), 1476-1504.

Tirabeni, L., \& Soderquist, K. E. (2019). Connecting the Dots: Framing Employee-Driven Innovation in Open Innovation Contexts. International Journal of Innovation and Technology Management, 16(04), 1950031. https://doi.org/10.1142/S0219877019500317

Urbinati, A., Chiaroni, D., Chiesa, V., \& Frattini, F. (2020). The role of digital technologies in open innovation processes: an exploratory multiple case study analysis. $R \& D$ Management, $50(1), 136-$ 160.

Van de Vrande, V., De Jong, J. P., Vanhaverbeke, W., \& De Rochemont, M. (2009). Open innovation in SMEs: Trends, motives and management challenges. Technovation, 29(6-7), 423437.

Vanhaverbeke, W., Chesbrough, H., \& West, J. (2014). Surfing the new wave of open innovation research. New frontiers in open innovation, 281, 287-288.

Vlajcic, D., Marzi, G., Caputo, A., \& Dabic, M. (2019). The role of geographical distance on the relationship between cultural intelligence and knowledge transfer. Business Process Management Journal. Vol. 25 No. 1, pp. 104-125. https://doi.org/10.1108/BPMJ-05-2017-0129 
Von Krogh, G., Netland, T., \& Wörter, M. (2018). Winning with open process innovation. MIT Sloan Management Review, 59(2), 53-56.

West, J., \& Bogers, M. (2014). Leveraging external sources of innovation: a review of research on open innovation. Journal of Product Innovation Management, 31(4), 814-831.

West, J., Salter, A., Vanhaverbeke, W., \& Chesbrough, H. (2014). Open innovation: The next decade.

Figure1. Conceptual Model

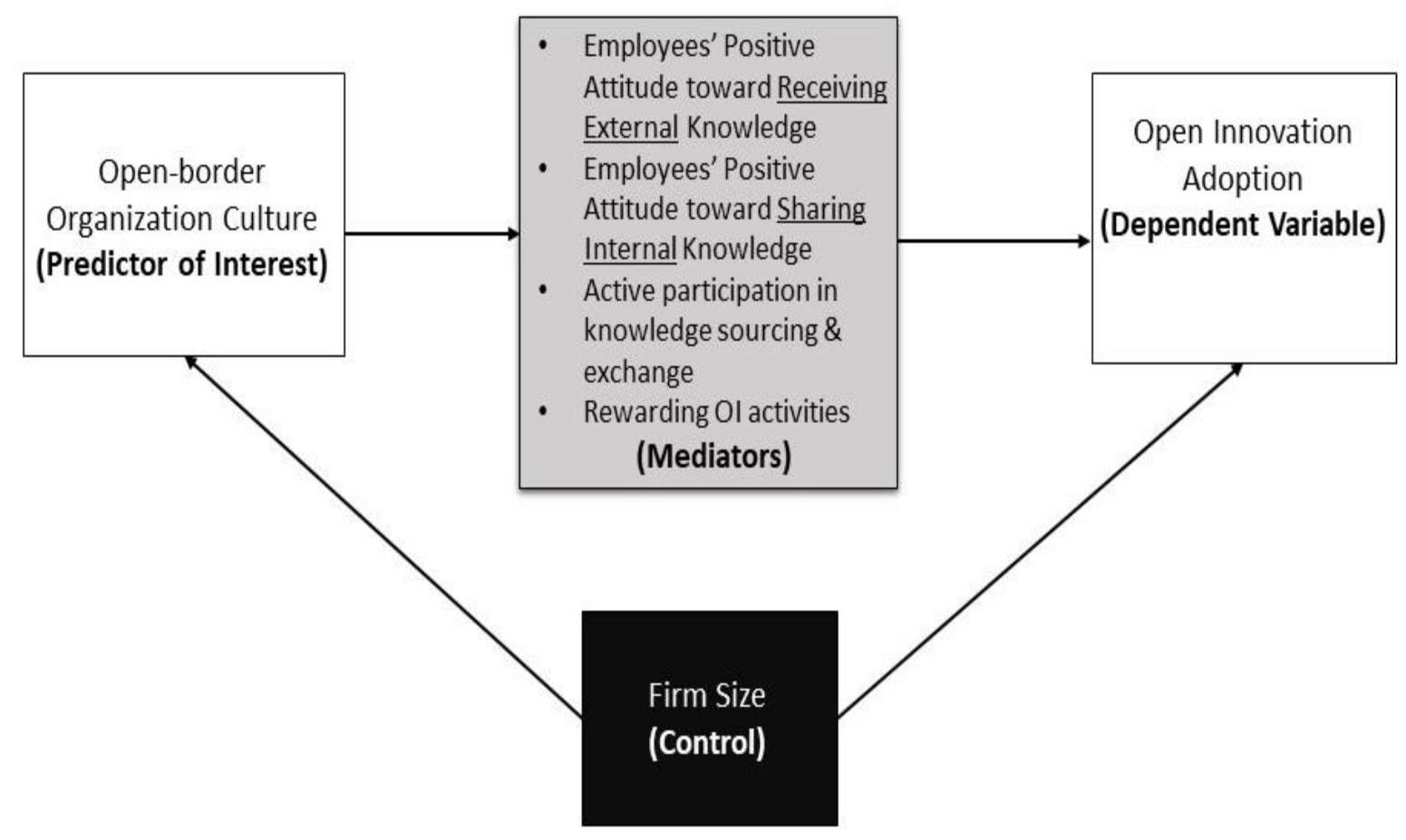


Table 1

Explanatory variables

\begin{tabular}{|c|c|c|c|c|}
\hline Variables & Definition & $\begin{array}{l}\text { Mean } \\
\text { (SD) }\end{array}$ & $\begin{array}{l}\text { Min } \\
\text { Value }\end{array}$ & $\begin{array}{l}\text { Max } \\
\text { Value }\end{array}$ \\
\hline Adopted OI & $\begin{array}{l}\text { Indicates if the organization has adopted Open } \\
\text { Innovation or not. }\end{array}$ & 0.32 & 0 & 1 \\
\hline Culture & $\begin{array}{l}\text { The organization has a culture of an open-border } \\
\text { type. }\end{array}$ & $\begin{array}{l}4.46 \\
(1.92)\end{array}$ & 1 & 7 \\
\hline EmpInt & $\begin{array}{l}\text { Employees' have a positive attitude towards } \\
\text { sharing knowledge that was created inside the } \\
\text { organization with external parties. }\end{array}$ & $\begin{array}{l}4.72 \\
(1.66)\end{array}$ & 1 & 7 \\
\hline EmpExt & $\begin{array}{l}\text { Employees' have a positive attitude towards } \\
\text { receiving knowledge that was created outside the } \\
\text { organization. }\end{array}$ & $\begin{array}{l}4.08 \\
(1.79)\end{array}$ & 1 & 7 \\
\hline Depts & $\begin{array}{l}\text { Relevant departments to Open Innovation active } \\
\text { participation in knowledge sourcing and exchange } \\
\text { activities. }\end{array}$ & $\begin{array}{l}4.18 \\
(1.71)\end{array}$ & 1 & 7 \\
\hline Rewards & $\begin{array}{l}\text { Employees receive rewards for engaging in Open } \\
\text { Innovation Activities. }\end{array}$ & $\begin{array}{l}3.51 \\
(1.96)\end{array}$ & 1 & 7 \\
\hline \multirow[t]{5}{*}{ Size } & Firm Size: & & & \\
\hline & Large & 0.44 & & \\
\hline & Medium & 0.19 & 1 & 4 \\
\hline & Small & 0.19 & & \\
\hline & Micro & 0.18 & & \\
\hline
\end{tabular}




\section{Table 2 Descriptive statistics}

\begin{tabular}{|c|c|c|c|}
\hline & $\begin{array}{l}\text { Mean or } \\
\text { Proportion }\end{array}$ & (SD) & Range \\
\hline Adopted open innovation & 0.32 & & {$[0,1]$} \\
\hline Open-border organization culture & 4.46 & $(1.92)$ & {$[1,7]$} \\
\hline $\begin{array}{l}\text { Employees' positive attitude towards receiving external } \\
\text { knowledge }\end{array}$ & 4.72 & $(1.66)$ & {$[1,7]$} \\
\hline $\begin{array}{l}\text { Employees' positive attitude towards sharing internal } \\
\text { knowledge }\end{array}$ & 4.08 & $(1.79)$ & {$[1,7]$} \\
\hline $\begin{array}{l}\text { Relevant departments active participation in knowledge } \\
\text { sourcing and exchange }\end{array}$ & 4.18 & $(1.71)$ & {$[1,7]$} \\
\hline Rewarding Open Innovation activities & 3.51 & $(1.96)$ & {$[1,7]$} \\
\hline Firm size: & & & {$[1,4]$} \\
\hline Large (ref) & 0.44 & & \\
\hline Medium & 0.19 & & \\
\hline Small & 0.19 & & \\
\hline Micro & 0.18 & & \\
\hline Firms (n) & $520 / 528$ & & \\
\hline
\end{tabular}


Table 3 Odds Ratio from Logistic Regression Model Predicting Organization's Open Innovation Addoption (a)

\begin{tabular}{|c|c|c|c|c|c|c|c|c|c|}
\hline & \multicolumn{3}{|c|}{ Model 1} & \multicolumn{3}{|c|}{ Model 2} & \multicolumn{3}{|c|}{ Model 3} \\
\hline & $\operatorname{Exp}(B)$ & & (SE) & $\operatorname{Exp}(B)$ & & (SE) & $\operatorname{Exp}(B)$ & & (SE) \\
\hline $\begin{array}{l}\text { Open-border } \\
\text { organization culture }\end{array}$ & 1.32 & $* * *$ & $(0.07)$ & 1.38 & $* * *$ & $(0.08)$ & 1.31 & $* * *$ & (0.09) \\
\hline Firm size: & & & & & & & & & \\
\hline Large(ref) & & & & - & & & - & & \\
\hline Medium & & & & 0.61 & & $(0.16)$ & 0.6 & & $(0.16)$ \\
\hline Small & & & & 0.43 & $* *$ & $(0.12)$ & 0.42 & $* *$ & $(0.12)$ \\
\hline Micro & & & & 0.44 & $* *$ & $(0.13)$ & 0.42 & $* *$ & $(0.12)$ \\
\hline $\begin{array}{l}\text { Employees' positive } \\
\text { attitude towards } \\
\text { receiving external } \\
\text { knowledge }\end{array}$ & & & & & & & 1.03 & & $(0.08)$ \\
\hline $\begin{array}{l}\text { Employees' positive } \\
\text { attitude towards } \\
\text { sharing internal } \\
\text { knowledge }\end{array}$ & & & & & & & 1.11 & & $(0.08)$ \\
\hline
\end{tabular}


Table 4 Odds Ratio from Logistic Regression Model Predicting Organization's Open Innovation Addoption (b)

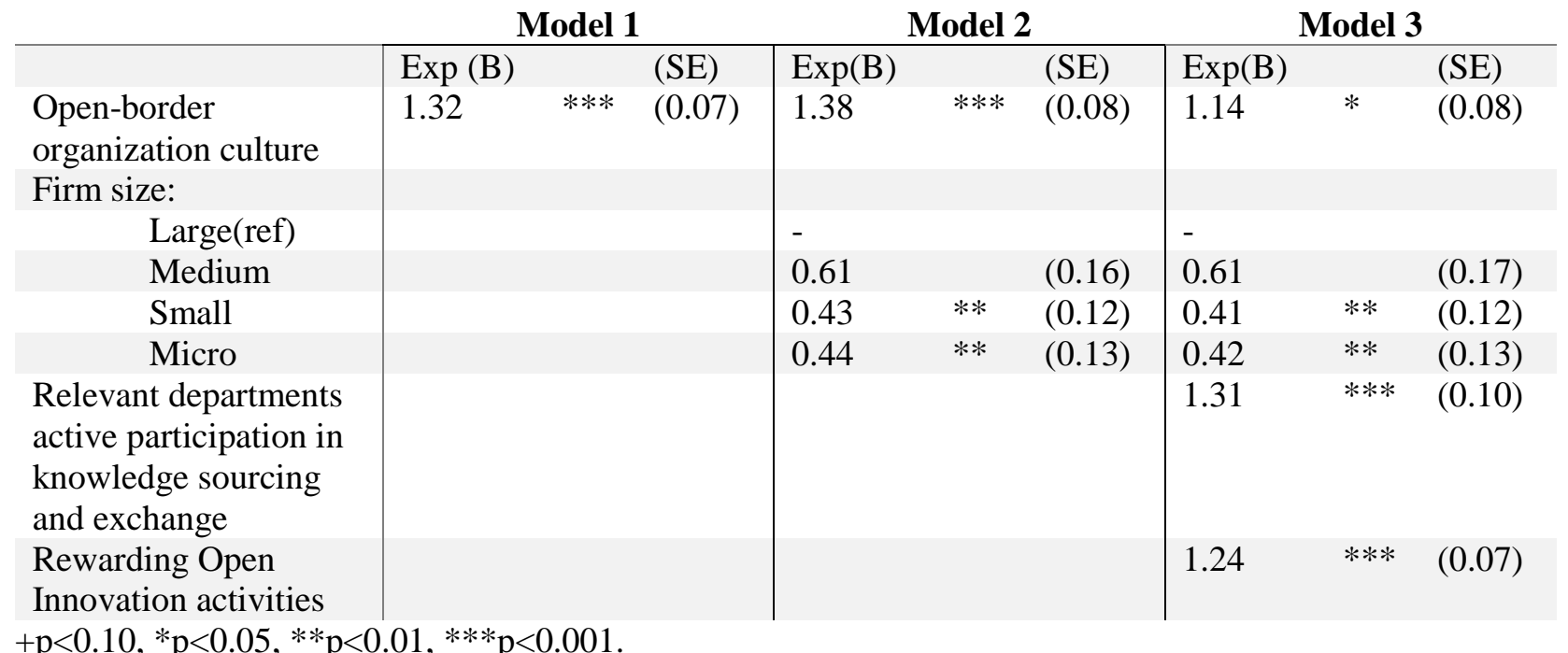




\section{Appendix}

\section{TABLE 5}

\begin{tabular}{|c|c|}
\hline COUNTRY (37) & $\begin{array}{l}\text { Albania (1); Austria (1); Belgium (2); Bosnia and Herzegovina (25); Brazil } \\
\text { (2); China (1); Croatia (26); Cyprus (1); Czech Republic (47); Denmark } \\
\text { (26); Estonia (3); Finland (23); France (4); Germany (25); Greece (59); } \\
\text { Hungary (45); Ireland (2); Italy (7); Latvia (27); Lithuania (1); Luxembourg } \\
\text { (3); Macedonia (26); Malta (15); Norway (3); Poland (10); Portugal (10); } \\
\text { Romania (9); Serbia (10); Slovakia (23); Slovenia (24); Spain (9); Sweden } \\
\text { (6); Switzerland (18); The Netherlands (12); Turkey (7); United Kingdom } \\
\text { (10); USA (4); Unknown (1). } \\
\text { Total: 528 }\end{array}$ \\
\hline INDUSTRY (28) & $\begin{array}{l}\text { Energy (29); Materials (27); Capital Goods (6); Commercial and } \\
\text { Professional Services (54); Transportation (18); Chemicals, Petroleum, and } \\
\text { Coal Products (12); Automobiles and Components (26); Consumer } \\
\text { Durables and Apparel (4); Hotels, Restaurants, and Leisure (7); Media (3); } \\
\text { Retailing (13); Food and Staples Retailing (5); Food, Beverages, and } \\
\text { Tobacco (20); Household and Personal Products (12); Health Care } \\
\text { Equipment and Services (8); Pharmaceuticals and Biotechnology (13); } \\
\text { Other (126); Banks (12); Diversified Financials (4); Insurance (5); Real } \\
\text { Estate (7); Software and Services (48); Technology Hardware and } \\
\text { Equipment (20); Semiconductors and Semiconductor Equipment (4); } \\
\text { Telecommunication Services (11); Utilities (3); Consulting (9); Education } \\
\text { (22). } \\
\text { Total:528 }\end{array}$ \\
\hline FIRM SIZE & $\begin{array}{l}\text { Large }>250(229) \\
\text { Medium-sized, } 50-249(102) \\
\text { Small, } 10-49(102) \\
\text { Micro, } 1-9(93) \\
\text { Not provided Information: } 2 \\
\text { Total: 528 }\end{array}$ \\
\hline
\end{tabular}




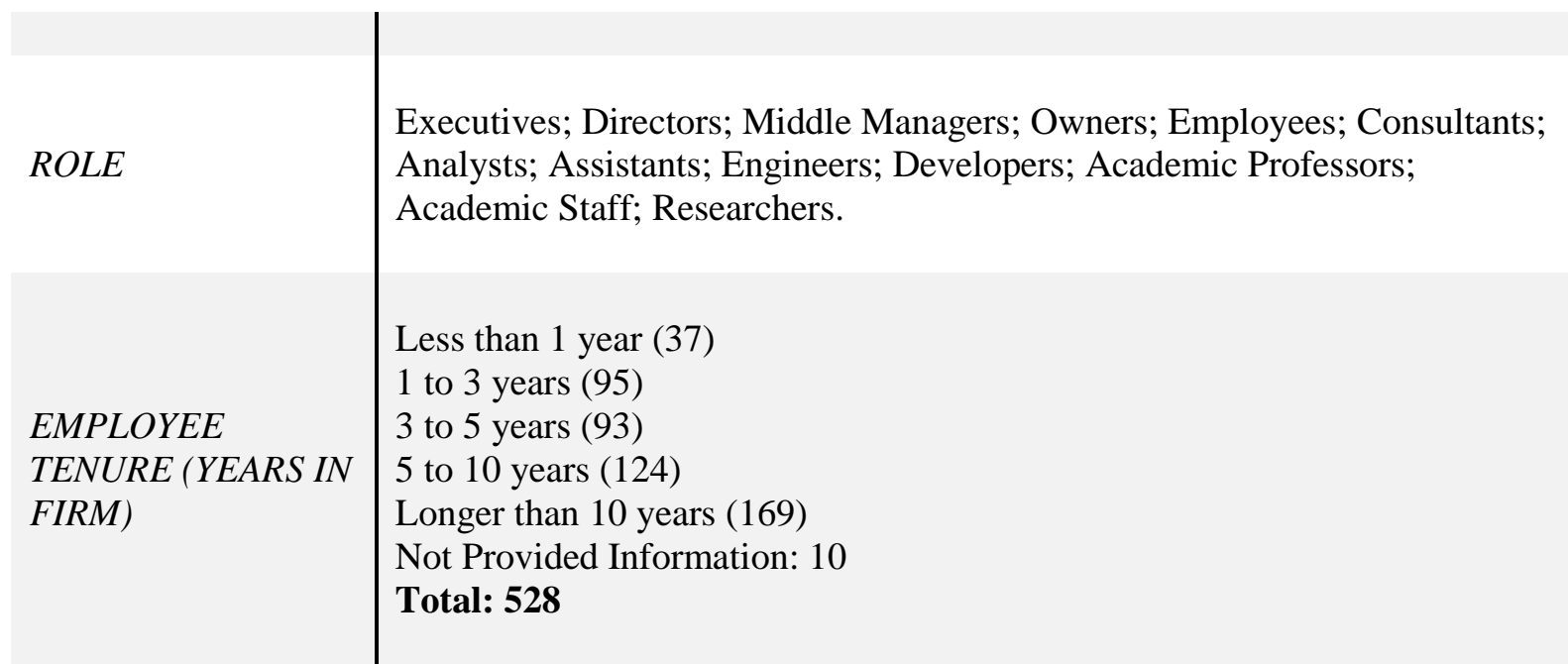

